\title{
DIET INFLUENCES THE GUT MICROBIOTA: A MINIREVIEW
}

\section{Manish Soni}

Address (es):

School of Engineering and Technology, Department of Biotechnology, SADTM Campus, Jaipur National University, Jagatpura, Jaipur, India-302017.

*Corresponding author: manishsoni888@ gmail.com

\section{ABSTRACT}

https://doi.org/10.36547/be.247

The human gut ecosystem is dynamic in nature which harbors trillions of microorganisms. These microorganisms constituting the gut microbiota are highly diverse and abundant having multiple implications on wellbeing and health of a person. There is a complex interaction between diet and microorganisms which can lead to beneficial or detrimental outcomes to host health. Each individual harbors specific and diverse microbiota depending upon his diet intake, genetic makeup, medication, metabolic regulations, external environment and his way of living the life. Among all these factors, diet plays a major role in deciding and influencing the microbiota of any person. The effects of diet on the gut microbiota are mostly temporary in nature. The microbiota of a person can be modulated by consumption of dietary fibres and prebiotics. This review focuses on the role of diet in influencing the gut microbiota of varied populations in different regions of the world.

Keywords: Microbiota, Microbiome, Microorganisms, Prebiotics, Probiotic

\section{GUT MICROBIOTA}

The collective genomes of the micro-organisms in a particular environment are referred to as Microbiome (Valdes et al., 2018). Trillions of microbial cells colonize human large intestine which are responsible for variations in host physiology and behavior (Whitman et al., 1998; Xu \& Knight, 2015). These gut microbiota plays a major role in assisting nutrient digestion, regulating host metabolism, providing resistance to pathogens and boosting immunity as illustrated in Figure 1. (Guarner \& Malagelada, 2003; Turnbaugh et al., 2006; Kelly et al., 2007; Neish, 2009; Qin et al., 2010). The microbiota is highly diverse which includes viruses, bacteria, fungi and protozoa in commensal with the gut (Lozupone et al., 2012; Gill et al., 2006; Eckburg et al., 2005). Firmicutes (gram positive bacteria) and Bacteroides (gram negative) are the predominant species in the human gut microbiota which act as an indicator of the gut microbiota composition (Flint et al., 2007; Walker et al., 2011, Hou et al., 2020). The mechanisms by which microbiome produces different byproducts and secondary metabolites in still poorly understood and is infancy stage of research. Some common species of microbiota harboring gut are listed in Table. 1.

Table 1 Gut Microbiota and their basic features

\begin{tabular}{|c|c|c|}
\hline Species Name & Characteristics Features & References \\
\hline Bifidobacterium $\mathrm{spp}$ & Gram positive obligate anaerobe branched; nonmotile & Pinzone et al., 2012; Schwiertz et al., 2010 \\
\hline Lactobacillus spp. & Gram positive facultative anaerobe rod-shaped & $\begin{array}{l}\text { Chen } \text { et al., 2009; Venturi et al., 1999, Hou et } \\
\text { al., } 2020\end{array}$ \\
\hline Bacteroides spp. & $\begin{array}{l}\text { Gram negative obligate anaerobe rod-shaped; variable } \\
\text { motility }\end{array}$ & $\begin{array}{l}\text { Raisch } \text { et al., 2016; Lucke, 2006; Wexler, 2007; } \\
\text { Prindiville, 2000 }\end{array}$ \\
\hline Bilophila spp. & $\begin{array}{l}\text { Gram negative obligate anaerobe urease-positive, bile } \\
\text { resistant, catalase-positive }\end{array}$ & Baron, 1997; Kamada et al., 2013 \\
\hline Clostridium spp. & Gram positive obligate anaerobe rod-shaped; spore-forming & $\begin{array}{l}\text { Baron, 1996; Gaboriau et al., 2009, Hou et al., } \\
2020\end{array}$ \\
\hline Eubacterium spp. & Gram positive obligate anaerobe rod-shaped & $\begin{array}{l}\text { Barcenilla et al., 2000; Schneider } \text { et al., 2000, } \\
\text { Hou } \text { et al., } 2020\end{array}$ \\
\hline Enterococcus spp. & Gram positive facultative anaerobe cocci & Fisher \& Phillips, 2009 \\
\hline Escherichia coli & Gram negative facultative anaerobe rod-shaped & $\begin{array}{l}\text { Rallabhandi et al., 2008; Todar, 2007; } \\
\text { Darfeuille } \text { et al., } 2004\end{array}$ \\
\hline Helicobacter pylori & Gram negative microaerophilic helix-shaped; motile & Kusters et al., 2006; Chang \& Parsonnet, 2010 \\
\hline Streptococcus spp. & Gram positive facultative anaerobe cocci & Patterson, 1996 \\
\hline $\begin{array}{l}\text { Faecalibacterium } \\
\text { prausnitzii }\end{array}$ & $\begin{array}{l}\text { anaerobic, gram-negative, non-spore-producing butyrate- } \\
\text { producing bacterium }\end{array}$ & $\begin{array}{l}\text { Hou et al., 2020; Lopez-Siles } \text { et al., 2012; } \\
\text { Heinken } \text { et al., 2014; Miquel } \text { et al., 2013; } \\
\text { Machiels et al., 2014 }\end{array}$ \\
\hline $\begin{array}{l}\text { Anaerostipes caccae \& } \\
\text { Anaerostipes hadrus }\end{array}$ & Butyrate producers, lactate and acetate utilizers & Duncan et al., 2004; Allen-Vercoe et al., 2012 \\
\hline
\end{tabular}

The microbiota of human gut is influenced by many factors like host genotype (Ley et al., 2005; Khachatryan et al., 2008; Benson et al., 2010), disease (Turnbaugh et al., 2006; Qin et al., 2010), diet (Harmsen et al., 2000; De Filippo et al., 2010) and external disturbances (De La Cochetiere et al., 2005; Dethlefsen \& Relman, 2010; van Vliet et al., 2009). 


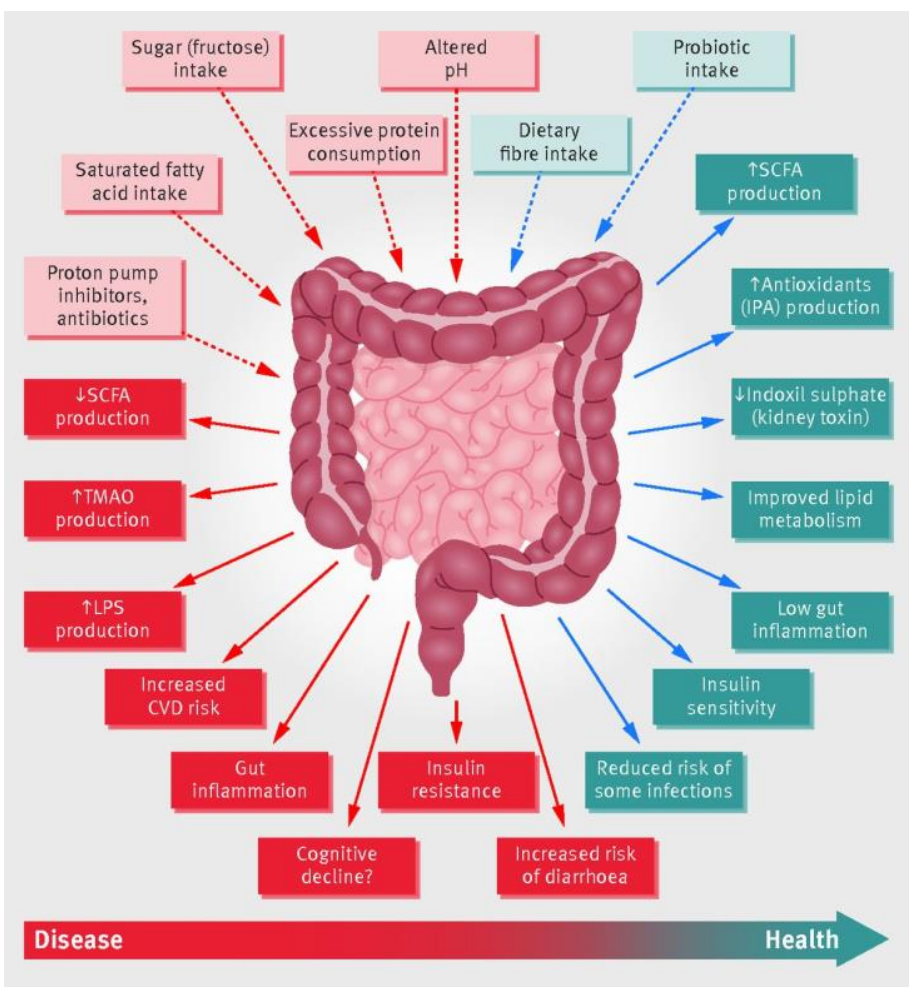

Figure 1 Role of the gut microbiota in health and disease (Valdes Ana et al., 2018)

\section{INFLUENCE OF DIET ON THE GUT MICROBIOTA OF A PERSON}

Diet of a person modulates the gut microbiota (genes are known as microbiome) influencing the well being and health of the person (Johnson et al., 2020). Human health is influenced by the interaction of the microbiota and the type of diet intake (Figure 2). The immune system is activated by the gut microbiota, they protect against the opportunistic pathogens, nutrient and energy is harvested from the diet by them (Chow et al., 2010; Fukuda et al., 2011; Sonnenburg et al., 2005). Any deviation in normal gut microbiota can cause obesity, diabetes and other pletheora of reactions (Turnbaugh et al., 2006; Kallus \& Brandt 2012; Qin et al., 2012). Apart from diet, gut microbiota is also influenced by genetic and environmental factors (Xu \& Knight 2015).

Different studies have been undertaken to show the response of microbiota species to the different dietary components. Protein, fats, probotics and carbohydrates induces different effects on gut microbiota (Singh et al. 2017). Diet components- diet composition, diet uptake habits or changes in diet have impact on the gut microbiota. Switching from a high-fat/ low-fiber to a lowfat/high-fiber diet affects the relative abundances of several microbial taxa in humans within 24 hrs (Wu et al., 2011; David et al., 2011). These diet-related changes may increase energy extraction from food and consequently alter host metabolic pathways (Sommer et al., 2016; Turnbaugh et al., 2008; Springer et al., 2017). A study done on the western population by Wu et al., (2011) has shown that the structure and composition of the human gut microbiota is influenced by the long-term dietary habits. They observed that the microbiota was enriched with Prevotella spp. in people with fiber and carbohydrate rich diets and whereas Bacteroides was major spp in the microbiota of people with diet rich in protein and fat. In an another study, it has been reported that people on a fat-restricted or a carbohydrate-restricted low-energy diet have increased ratio of Bacteroidetes:Firmicutes in their gut microbiota (Ley et al., 2006). In a similar way, studies on Asian population have also been conducted to evaluate their gut microbiota. Hou et al., (2020) observed that in all participants of Asian populations harbors Faecalibacterium prausnitzii in their gut. This species is used as a potential probiotic and alleviates diabetic symptoms and have immunomodulatory effect; hence maintains health of Asian population. Mediterranean diet constituting eggs, chicken, sea food and fruits which are a rich source of Vitamin $\mathrm{A}$ and Vitamin $\mathrm{B}_{5}$ promotes and favors the growth of Prevotella spp. in the gut microbiota (David et al., 2014; De Filippis et al., 2016). In another study, Brassica consumption was associated with decrease in sulphate-producing bacteria (Kellingray et al., 2017).

Microbiota composition is also determined by the fiber content in the diet of a person (Chassaing et al., 2017). In a study, dietary fibre- fructans and galactooligosaccharides resulted in an increase in Bifidobacterium and Lactobacillus species in faecal matter of the subjects (So et al., 2018). Fruits and grain fibre also influences gut microbiota (Johnson et al., 2019).

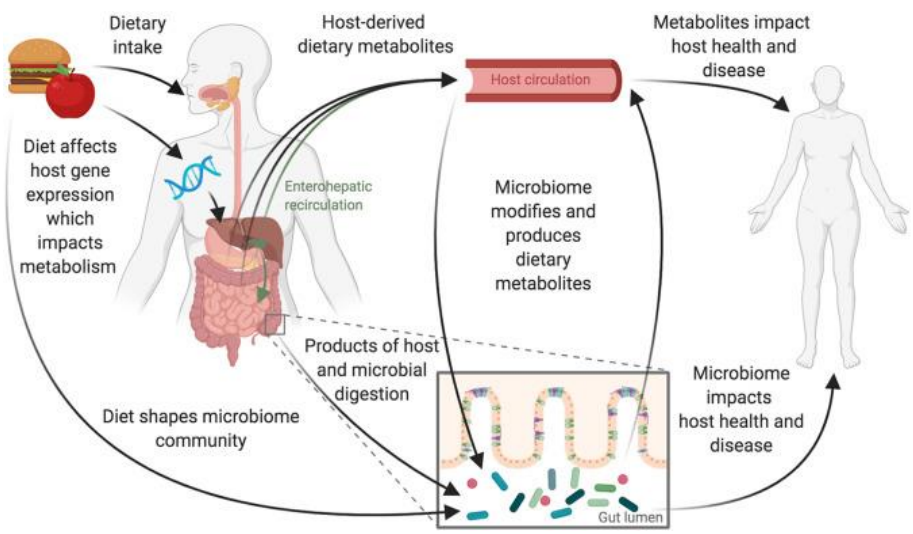

Figure 2 Interaction of Gut Microbiota and Diet Influences Human Health (Johnson et al., 2020)

\section{PROBIOTICS AND GUT MICROBIOTA}

Certain live microorganisms conferring health benefits when administered in adequate quantity are popularly known as Probiotics. These probiotics colonize and proliferate in the GI tract and alter the gut microbiota. The potential benefits of probiotics are in the treatment of infectious- and antibiotic-associated diarrhoea, insulin resistance in diabetes, and remission and maintenance of inflammatory bowel disease ( $\mathrm{Li}$ et al., 2019; Hungin et al., 2018; Derwa et al., 2017; Krumbeck et al., 2018). The variability is very high in establishing probiotics as a part of gut microbial community as they have to compete against the host microbes for substrates for theie survival (Shepherd et al., 2018).

\section{PREBIOTICS AND GUT MICROBIOTA}

Fibre content of certain food compounds like fruit, vegetables, legumes, grains and nuts is very high and has beneficial effects on the health. The term prebiotics is defined as "a substrate that is selectively used by host microorganisms conferring a health benefit" (Ferrarese et al., 2018; Gibson et al., 2017). Inulin, FOS and GOS are the common examples of prebiotics present in dietary fibres. They favor the health promoting microorganism in gut microbiota. These prebiotic compounds are resistant to gastric acid and hydrolytic activity of the digestive enzymes and therefore are metabolized in the colon by the microbiota. The metabolism of these prebiotics results in the production of short-chain fatty acids (SCFAs), including acetate, propionate and butyrate (Holscher, 2017). Different studies have shown the growth promoting effect of prebiotics on Bifidobacterium and Lactobacillus and Lactic acid bacteria (Gibson \& Roberfroid, 1995; Macfarlane et al., 2006; Gibson et al., 2017; Dewulf et al., 2013). Faecalibacterium prausnitzii (a butyrate- producing bacteria) and Akkermansia muciniphila (a mucin degrading bacterium) have beneficial health effects- reduces inflammation and improves gut barrier function (Thomas et al., 2015). The dietary fibre or prebiotics impacts the human GI microbiota both functionally and in composition which has been briefly illustrated in Table. 2 (Holscher, 2017) and Figure 3. 
Table 2 Impact of Dietary Fibre or Prebitic on GI Microbiota

\begin{tabular}{|c|c|c|}
\hline Dietary Fibre or Prebiotic & Changes in Microbiota & References \\
\hline Arabinoxylan-oligosaccharies & Increased Lactobacilli, Bacteroides, Bifidobacterium & $\begin{array}{l}\text { Walton et al., 2012; Francois et } \\
\text { al., 2012, Francois et al., } 2014\end{array}$ \\
\hline Whole grains & No significant changes & Ampatzoglou et al., 2015 \\
\hline Galactooligosaccharides & $\begin{array}{l}\text { Increase Bifidobacterium spp, } \\
\text { Bacteroides spp, }\end{array}$ & Vulevic et al., 2015 \\
\hline Inulin + oligofructose & $\begin{array}{l}\text { Increased Bifidobacterium longum, Bifidobacterium pseudocatenulatum } \\
\text { and Bifidobacterium adolescentis }\end{array}$ & Salazar et al., 2014 \\
\hline Xylooligosaccharide & Increased Bifidobacterium, Bacteroides fragilis & Finegold et al., 2014 \\
\hline Polydextrose & $\begin{array}{l}\text { decreased C. histolyticum, } \\
\text { lactobacilli/enterococci } \\
\text { Increased Clostridium coccoides, Clostridium leptum, Lactobacillus spp, }\end{array}$ & Costabile et al., 2012 \\
\hline $\begin{array}{l}\text { Butyrylated high-amylose } \\
\text { maize starch, }\end{array}$ & $\begin{array}{l}\text { Parabacteroides distasonis and Ruminococcus bromii } \\
\text { Decreased Ruminococcus torques and Ruminococcus gnavus, } \\
\text { Ruminococcus torques and Escherichia coli }\end{array}$ & Le Leu et al., 2015 \\
\hline Resistant starch & $\begin{array}{l}\text { Increased Oscillospira guillermondii, R. bromii, Sporobacter termitis, } \\
\text { Clostridium leptum, C. cellulosi, Alistipes spp, E. rectal, } \\
\text { Decreased Papillibacter cinnamivorans, }\end{array}$ & Salonen et al., 2014 \\
\hline Non-starch polysaccharides & $\begin{array}{l}\text { Increased Eggerthella, Collinsella, Corynebacterium, Bacteroides vulgatus } \\
\text { and Prevotella oralis } \\
\text { Decreased: C. leptum, C. cellulosi, Oscillospira spp and Sprorobacter spp }\end{array}$ & Salonen et al., 2014 \\
\hline
\end{tabular}

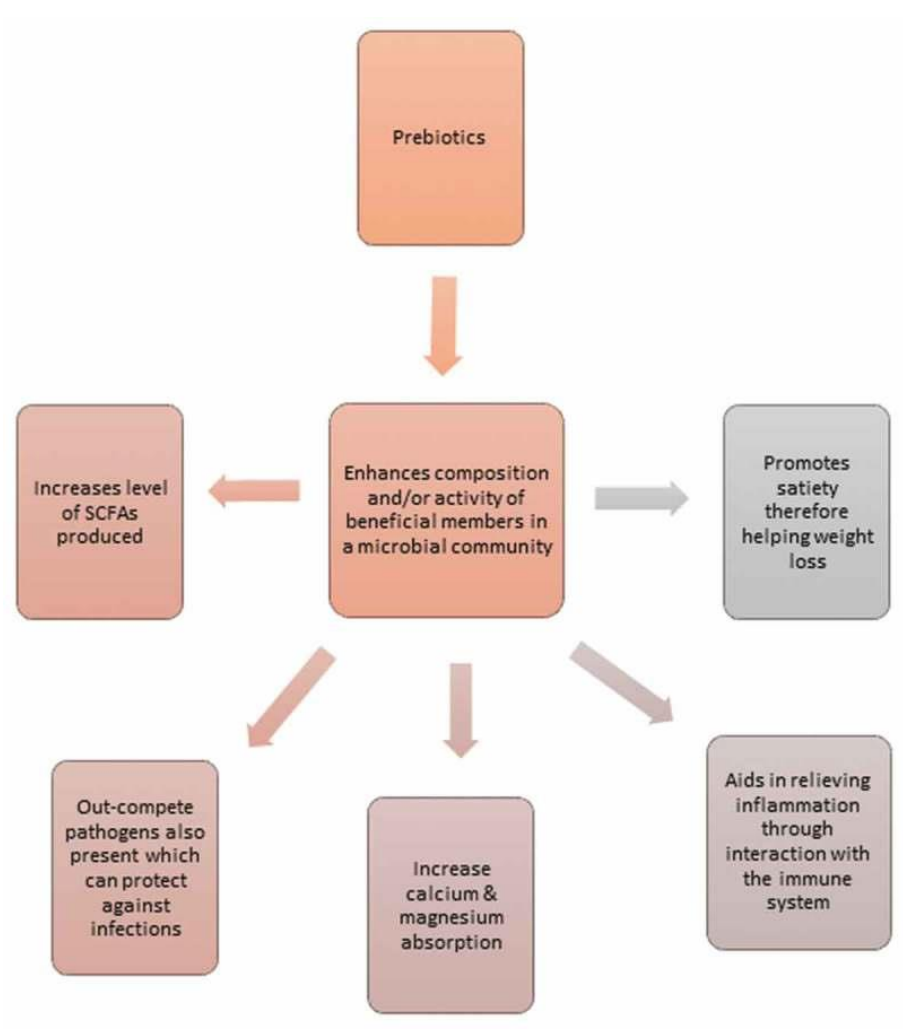

Figure 3 Beneficial impacts of prebiotic on the gut microbiota (Cathy et al., 2020)

\section{CONCLUSIONS}

The interaction between host and gut microbiota is multi-faceted and highly complex; a balance of benefit and harm depends on many dietary and microbial factors. Diet can significantly influence and alter the gut microbiota of a person. The major dietary components affecting the gut microbiota are fibre, fruits, vegetables, carbohydrates, protein and other plant foods. More elaborative studies on the mechanisms involved in interaction of gut microbiota and diet need to be carried out to answer plethora of questions like role of diet induced microbiota in obesity, diabetes and other disorders. Therapeutic dietetic strategies on the microbiota further requires understanding of the relation between diet and gut microbiota. The dietary modulation of the gut microbiota for health can be clinically recommended after extensive and elaborative research in this direction.

\section{REFERENCES}

Allen-Vercoe, E., Daigneault, M., White, A., Panaccione, R., Duncan, S. H., Flint, H. J., O'Neal, L., \& Lawson, P. A. (2012). Anaerostipes hadrus comb. nov., a dominant species within the human colonic microbiota; reclassification of Eubacterium hadrum Moore et al. 1976. Anaerobe, 18(5), 523-529. https://doi.org/10.1016/j.anaerobe.2012.09.002

Ampatzoglou, A., Atwal, K. K., Maidens, C. M., Williams, C. L., Ross, A. B., Thielecke, F., Jonnalagadda, S. S., Kennedy, O. B., \& Yaqoob, P. (2015). Increased whole grain consumption does not affect blood biochemistry, body composition, or gut microbiology in healthy, low-habitual whole grain consumers. The Journal of nutrition, 145(2), 215-221. https://doi.org/10.3945/jn.114.202176

Barcenilla, A., Pryde, S. E., Martin, J. C., Duncan, S. H., Stewart, C. S., Henderson, C., \& Flint, H. J. (2000). Phylogenetic relationships of butyrateproducing bacteria from the human gut. Applied and environmental microbiology, 66(4), 1654-1661. https://doi.org/10.1128/aem.66.4.16541661.2000

Baron. E. J. (1997). Bilophila wadsworthia: a unique gram-negative anaerobic rod. Anaerobe. 3, 83-6. https://doi.org/10.1006/anae.1997.0075

Baron. S. (1996). Clostridium. Baron's Med. microbiol. $4^{\text {th }}$ ed. Galveston: University of Texas Medical Branch.

Benson, A. K., Kelly, S. A., Legge, R., Ma, F., Low, S. J., Kim, J., Zhang, M., Oh, P. L., Nehrenberg, D., Hua, K., Kachman, S. D., Moriyama, E. N., Walter, J., Peterson, D. A., \& Pomp, D. (2010). Individuality in gut microbiota composition is a complex polygenic trait shaped by multiple environmental and host genetic factors. Proceedings of the National Academy of Sciences of the United States of America, 107(44), 18933-18938. https://doi.org/10.1073/pnas.1007028107

Chang, A. H., \& Parsonnet, J. (2010). Role of bacteria in oncogenesis. Clinical microbiology reviews, 23(4), 837-857. https://doi.org/10.1128/CMR.00012-10

Chassaing, B., Vijay-Kumar, M., \& Gewirtz, A. T. (2017). How diet can impact gut microbiota to promote or endanger health. Current opinion in gastroenterology, 33(6), 417-421. https://doi.org/10.1097/MOG.0000000000000401

Chen, X., Fruehauf, J., Goldsmith, J. D., Xu, H., Katchar, K. K., Koon, H. W., Zhao, D., Kokkotou, E. G., Pothoulakis, C., \& Kelly, C. P. (2009). Saccharomyces boulardii inhibits EGF receptor signaling and intestinal tumor growth in Apc(min) mice. Gastroenterology, 137(3), 914-923. https://doi.org/10.1053/j.gastro.2009.05.050

Chow, J., Lee, S. M., Shen, Y., Khosravi, A., \& Mazmanian, S. K. (2010). Hostbacterial symbiosis in health and disease. Advances in immunology, 107, 243274. https://doi.org/10.1016/B978-0-12-381300-8.00008-3 
Costabile, A., Fava, F., Roytio, H., Forssten, S. D., Olli, K., Klievink, J., Rowland, I. R., Ouwehand, A. C., Rastall, R. A., Gibson, G. R., \& Walton, G. E. (2012). Impact of polydextrose on the faecal microbiota: a double-blind, crossover, placebo-controlled feeding study in healthy human subjects. The British journal of nutrition. 108(3), 471-481. https://doi.org/10.1017/S0007114511005782

Darfeuille-Michaud, A., Boudeau, J., Bulois, P., Neut, C., Glasser, A. L., Barnich, N., Bringer, M. A., Swidsinski, A., Beaugerie, L., \& Colombel, J. F. (2004). High prevalence of adherent-invasive Escherichia coli associated with ileal mucosa in Crohn's disease. Gastroenterology, 127(2), 412-421. https://doi.org/10.1053/j.gastro.2004.04.061

David, L. A., Maurice, C. F., Carmody, R. N., Gootenberg, D. B., Button, J. E., Wolfe, B. E., Ling, A. V., Devlin, A. S., Varma, Y., Fischbach, M. A., Biddinger, S. B., Dutton, R. J., \& Turnbaugh, P. J. (2014). Diet rapidly and reproducibly alters the human gut microbiome. Nature, 505(7484), 559-563. https://doi.org/10.1038/nature12820

De Filippis, F., Pellegrini, N., Vannini, L., Jeffery, I. B., La Storia, A., Laghi, L., Serrazanetti, D. I., Di Cagno, R., Ferrocino, I., Lazzi, C., Turroni, S., Cocolin, L., Brigidi, P., Neviani, E., Gobbetti, M., O'Toole, P. W., \& Ercolini, D. (2016). High-level adherence to a Mediterranean diet beneficially impacts the gut microbiota and associated metabolome. Gut, 65(11), 1812-1821. https://doi.org/10.1136/gutjnl-2015-309957

De Filippo, C., Cavalieri, D., Di Paola, M., Ramazzotti, M., Poullet, J. B., Massart, S., Collini, S., Pieraccini, G., \& Lionetti, P. (2010). Impact of diet in shaping gut microbiota revealed by a comparative study in children from Europe and rural Africa. Proceedings of the National Academy of Sciences of the United States of America, 107(33), 14691-14696. https://doi.org/10.1073/pnas.1005963107

De La Cochetiere, M. F., Durand, T., Lepage, P., Bourreille, A., Galmiche, J. P., \& Dore, J. (2005). Resilience of the dominant human fecal microbiota upon short-course antibiotic challenge. Journal of clinical microbiology, 43(11), 55885592. https://doi.org/10.1128/JCM.43.11.5588-5592.2005

Derwa, Y., Gracie, D. J., Hamlin, P. J., \& Ford, A. C. (2017). Systematic review with meta-analysis: the efficacy of probiotics in inflammatory bowel disease. Alimentary pharmacology \& therapeutics, 46(4), 389-400. https://doi.org/10.1111/apt.14203

Dethlefsen, L., \& Relman, D. A. (2011). Incomplete recovery and individualized responses of the human distal gut microbiota to repeated antibiotic perturbation. Proceedings of the National Academy of Sciences of the United States of America, $108 \quad$ Suppl 1(Suppl 1), 4554-4561. https://doi.org/10.1073/pnas.1000087107

Dewulf, E. M., Cani, P. D., Claus, S. P., Fuentes, S., Puylaert, P. G., Neyrinck, A. M., Bindels, L. B., de Vos, W. M., Gibson, G. R., Thissen, J. P., \& Delzenne, N. M. (2013). Insight into the prebiotic concept: lessons from an exploratory, double blind intervention study with inulin-type fructans in obese women. Gut, 62(8), 1112-1121. https://doi.org/10.1136/gutjnl-2012-303304

Duncan, S. H., Louis, P., \& Flint, H. J. (2004). Lactate-utilizing bacteria, isolated from human feces, that produce butyrate as a major fermentation product. Applied and environmental microbiology, 70(10), 5810-5817. https://doi.org/10.1128/AEM.70.10.5810-5817.2004

Eckburg, P. B., Bik, E. M., Bernstein, C. N., Purdom, E., Dethlefsen, L., Sargent, M., Gill, S. R., Nelson, K. E., \& Relman, D. A. (2005). Diversity of the human intestinal microbial flora. Science (New York, N.Y.), 308(5728), 1635-1638. https://doi.org/10.1126/science.1110591

Faecalibacterium prausnitzii and human intestinal health. Current opinion in microbiology, 16(3), 255-261. https://doi.org/10.1016/j.mib.2013.06.003

Ferrarese, R., Ceresola, E. R., Preti, A., \& Canducci, F. (2018). Probiotics, prebiotics and synbiotics for weight loss and metabolic syndrome in the microbiome era. European review for medical and pharmacological sciences, 22(21), 7588-7605. https://doi.org/10.26355/eurrev_201811_16301

Finegold, S. M., Li, Z., Summanen, P. H., Downes, J., Thames, G., Corbett, K., Dowd, S., Krak, M., \& Heber, D. (2014). Xylooligosaccharide increases bifidobacteria but not lactobacilli in human gut microbiota. Food \& function, 5(3), 436-445. https://doi.org/10.1039/c3fo60348b

Fisher, K., \& Phillips, C. (2009). The ecology, epidemiology and virulence of Enterococcus. Microbiology (Reading, England), 155(Pt 6), 1749-1757. https://doi.org/10.1099/mic.0.026385-0

Flint, H. J., Duncan, S. H., Scott, K. P., \& Louis, P. (2007). Interactions and competition within the microbial community of the human colon: links between diet and health. Environmental microbiology, 9(5), 1101-1111. https://doi.org/10.1111/j.1462-2920.2007.01281.x

Francois, I. E., Lescroart, O., Veraverbeke, W. S., Marzorati, M., Possemiers, S., Evenepoel, P., Hamer, H., Houben, E., Windey, K., Welling, G. W., Delcour, J. A., Courtin, C. M., Verbeke, K., \& Broekaert, W. F. (2012). Effects of wheat bran extract containing arabinoxylan oligosaccharides on gastrointestinal health parameters in healthy adult human volunteers: a double-blind, randomised, placebo-controlled, cross-over trial. The British journal of nutrition, 108(12), 2229-2242. https://doi.org/10.1017/S0007114512000372

Francois, I. E., Lescroart, O., Veraverbeke, W. S., Marzorati, M., Possemiers, S., Hamer, H., Windey, K., Welling, G. W., Delcour, J. A., Courtin, C. M., Verbeke, K., \& Broekaert, W. F. (2014). Effects of wheat bran extract containing arabinoxylan oligosaccharides on gastrointestinal parameters in healthy preadolescent children. Journal of pediatric gastroenterology and nutrition, 58(5), 647-653. https://doi.org/10.1097/MPG.0000000000000285

Fukuda, S., Toh, H., Hase, K., Oshima, K., Nakanishi, Y., Yoshimura, K., Tobe, T., Clarke, J. M., Topping, D. L., Suzuki, T., Taylor, T. D., Itoh, K., Kikuchi, J., Morita, H., Hattori, M., \& Ohno, H. (2011). Bifidobacteria can protect from enteropathogenic infection through production of acetate. Nature, 469(7331), 543-547. https://doi.org/10.1038/nature09646

Gaboriau-Routhiau, V., Rakotobe, S., Lécuyer, E., Mulder, I., Lan, A., Bridonneau, C., Rochet, V., Pisi, A., De Paepe, M., Brandi, G., Eberl, G., Snel, J., Kelly, D., \& Cerf-Bensussan, N. (2009). The key role of segmented filamentous bacteria in the coordinated maturation of gut helper $\mathrm{T}$ cell responses. Immunity, 31(4), 677-689. https://doi.org/10.1016/j.immuni.2009.08.020

Gibson, G. R., \& Roberfroid, M. B. (1995). Dietary modulation of the human colonic microbiota: introducing the concept of prebiotics. The Journal of nutrition, 125(6), 1401-1412. https://doi.org/10.1093/jn/125.6.1401

Gibson, G. R., Hutkins, R., Sanders, M. E., Prescott, S. L., Reimer, R. A., Salminen, S. J., Scott, K., Stanton, C., Swanson, K. S., Cani, P. D., Verbeke, K., \& Reid, G. (2017). Expert consensus document: The International Scientific Association for Probiotics and Prebiotics (ISAPP) consensus statement on the definition and scope of prebiotics. Nature reviews. Gastroenterology \& hepatology, 14(8), 491-502. https://doi.org/10.1038/nrgastro.2017.75

Gill, S. R., Pop, M., Deboy, R. T., Eckburg, P. B., Turnbaugh, P. J., Samuel, B. S., Gordon, J. I., Relman, D. A., Fraser-Liggett, C. M., \& Nelson, K. E. (2006). Metagenomic analysis of the human distal gut microbiome. Science (New York, N.Y.), 312(5778), 1355-1359. https://doi.org/10.1126/science.1124234

Guarner, F., \& Malagelada, J. R. (2003). Gut flora in health and disease. Lancet (London, England), 361(9356), 512-519. https://doi.org/10.1016/S0140$\underline{6736(03) 12489-0}$

Harmsen, H. J., Wildeboer-Veloo, A. C., Raangs, G. C., Wagendorp, A. A., Klijn, N., Bindels, J. G., \& Welling, G. W. (2000). Analysis of intestinal flora development in breast-fed and formula-fed infants by using molecular identification and detection methods. Journal of pediatric gastroenterology and nutrition, 30(1), 61-67. https://doi.org/10.1097/00005176-200001000-00019 Heinken, A., Khan, M. T., Paglia, G., Rodionov, D. A., Harmsen, H. J., \& Thiele, I. (2014). Functional metabolic map of Faecalibacterium prausnitzii, a beneficial human gut microbe. Journal of bacteriology, 196(18), 3289-3302. https://doi.org/10.1128/JB.01780-14

Holscher H. D. (2017). Dietary fiber and prebiotics and the gastrointestinal microbiota. Gut microbes, 8(2), 172-184. https://doi.org/10.1080/19490976.2017.1290756

Hou, Q., Zhao, F., Liu, W., Lv, R., Khine, W., Han, J., Sun, Z., Lee, Y. K., \& Zhang, H. (2020). Probiotic-directed modulation of gut microbiota is basal microbiome dependent. Gut microbes, 12(1), 1736974. https://doi.org/10.1080/19490976.2020.1736974

Hungin, A., Mitchell, C. R., Whorwell, P., Mulligan, C., Cole, O., Agréus, L., Fracasso, P., Lionis, C., Mendive, J., Philippart de Foy, J. M., Seifert, B., Wensaas, K. A., Winchester, C., de Wit, N., \& European Society for Primary Care Gastroenterology (2018). Systematic review: probiotics in the management of lower gastrointestinal symptoms - an updated evidence-based international consensus. Alimentary pharmacology \& therapeutics, 47(8), 1054-1070. https://doi.org/10.1111/apt.14539

Johnson, A. J., Vangay, P., Al-Ghalith, G. A., Hillmann, B. M., Ward, T. L., Shields-Cutler, R. R., Kim, A. D., Shmagel, A. K., Syed, A. N., Personalized Microbiome Class Students, Walter, J., Menon, R., Koecher, K., \& Knights, D. (2019). Daily Sampling Reveals Personalized Diet-Microbiome Associations in Humans. Cell host \& microbe, 25(6), 789-802.e5. https://doi.org/10.1016/j.chom.2019.05.005 
Johnson, A. J., Zheng, J. J., Kang, J. W., Saboe, A., Knights, D., \& Zivkovic, A. M. (2020). A Guide to Diet-Microbiome Study Design. Frontiers in nutrition, 7, 79. https://doi.org/10.3389/fnut.2020.00079

Kallus, S. J., \& Brandt, L. J. (2012). The intestinal microbiota and obesity. Journal of clinical gastroenterology, 46(1), 16-24. https://doi.org/10.1097/MCG.0b013e31823711fd

Kamada, N., Seo, S. U., Chen, G. Y., \& Nunez, G. (2013). Role of the gut microbiota in immunity and inflammatory disease. Nature reviews. Immunology, 13(5), 321-335. https://doi.org/10.1038/nri3430

Kellingray, L., Tapp, H. S., Saha, S., Doleman, J. F., Narbad, A., \& Mithen, R. F. (2017). Consumption of a diet rich in Brassica vegetables is associated with a reduced abundance of sulphate-reducing bacteria: A randomised crossover study. Molecular nutrition \& food research, 61(9), 1600992. https://doi.org/10.1002/mnfr.201600992

Kelly, D., King, T., \& Aminov, R. (2007). Importance of microbial colonization of the gut in early life to the development of immunity. Mutation research, 622(1-2), 58-69. https://doi.org/10.1016/j.mrfmmm.2007.03.011

Khachatryan, Z. A., Ktsoyan, Z. A., Manukyan, G. P., Kelly, D., Ghazaryan, K. A., \& Aminov, R. I. (2008). Predominant role of host genetics in controlling the composition of gut microbiota. PloS one, 3(8), e3064. https://doi.org/10.1371/journal.pone.0003064

Krumbeck, J. A., Walter, J., \& Hutkins, R. W. (2018). Synbiotics for Improved Human Health: Recent Developments, Challenges, and Opportunities. Annual review of food science and technology, 9, 451-479. https://doi.org/10.1146/annurev-food-030117-012757

Kusters, J. G., van Vliet, A. H., \& Kuipers, E. J. (2006). Pathogenesis of Helicobacter pylori infection. Clinical microbiology reviews, 19(3), 449-490. https://doi.org/10.1128/CMR.00054-05

Le Leu, R. K., Winter, J. M., Christophersen, C. T., Young, G. P., Humphreys, K. J., Hu, Y., Gratz, S. W., Miller, R. B., Topping, D. L., Bird, A. R., \& Conlon, M. A. (2015). Butyrylated starch intake can prevent red meat-induced O6-methyl-2deoxyguanosine adducts in human rectal tissue: a randomised clinical trial. The British journal of nutrition, 114(2), 220-230. https://doi.org/10.1017/S0007114515001750

Ley, R. E., Bäckhed, F., Turnbaugh, P., Lozupone, C. A., Knight, R. D., \& Gordon, J. I. (2005). Obesity alters gut microbial ecology. Proceedings of the National Academy of Sciences of the United States of America, 102(31), 1107011075. https://doi.org/10.1073/pnas.0504978102

Ley, R. E., Turnbaugh, P. J., Klein, S., \& Gordon, J. I. (2006). Microbial ecology: human gut microbes associated with obesity. Nature, 444(7122), 10221023. https://doi.org/10.1038/4441022a

Li, Y. T., Xu, H., Ye, J. Z., Wu, W. R., Shi, D., Fang, D. Q., Liu, Y., \& Li, L. J. (2019). Efficacy of Lactobacillus rhamnosus GG in treatment of acute pediatric diarrhea: A systematic review with meta-analysis. World journal of gastroenterology, 25(33), 4999-5016. https://doi.org/10.3748/wjg.v25.i33.4999 Lopez-Siles, M., Khan, T. M., Duncan, S. H., Harmsen, H. J., Garcia-Gil, L. J., \& Flint, H. J. (2012). Cultured representatives of two major phylogroups of human colonic Faecalibacterium prausnitzii can utilize pectin, uronic acids, and hostderived substrates for growth. Applied and environmental microbiology, 78(2), 420-428. https://doi.org/10.1128/AEM.06858-11

Lordan, C., Thapa, D., Ross, R. P., \& Cotter, P. D. (2020). Potential for enriching next-generation health-promoting gut bacteria through prebiotics and other dietary components. Gut microbes, 11(1), 1-20. https://doi.org/10.1080/19490976.2019.1613124

Lozupone, C. A., Stombaugh, J. I., Gordon, J. I., Jansson, J. K., \& Knight, R. (2012). Diversity, stability and resilience of the human gut microbiota. Nature, 489(7415), 220-230. https://doi.org/10.1038/nature11550

Lucke, K., Miehlke, S., Jacobs, E., \& Schuppler, M. (2006). Prevalence of Bacteroides and Prevotella spp. in ulcerative colitis. Journal of medical microbiology, 55(Pt 5), 617-624. https://doi.org/10.1099/jmm.0.46198-0

Macfarlane, S., Macfarlane, G. T., \& Cummings, J. H. (2006). Review article: prebiotics in the gastrointestinal tract. Alimentary pharmacology \& therapeutics, 24(5), 701-714. https://doi.org/10.1111/j.1365-2036.2006.03042.x

Machiels, K., Joossens, M., Sabino, J., De Preter, V., Arijs, I., Eeckhaut, V., Ballet, V., Claes, K., Van Immerseel, F., Verbeke, K., Ferrante, M., Verhaegen, J., Rutgeerts, P., \& Vermeire, S. (2014). A decrease of the butyrate-producing species Roseburia hominis and Faecalibacterium prausnitzii defines dysbiosis in patients with ulcerative colitis. Gut, 63(8), 1275-1283. https://doi.org/10.1136/gutjnl-2013-304833
Miquel, S., Martín, R., Rossi, O., Bermúdez-Humarán, L. G., Chatel, J. M., Sokol, H., Thomas, M., Wells, J. M., \& Langella, P. (2013).

Neish A. S. (2009). Microbes in gastrointestinal health and disease. Gastroenterology, 136(1), 65-80. https://doi.org/10.1053/j.gastro.2008.10.080

Patterson MJ. Streptococcus. In: Baron S, editor. Medical Microbiology. 4th edition. Galveston (TX): University of Texas Medical Branch at Galveston; 1996. Chapter 13. Available from: https://www.ncbi.nlm.nih.gov/books/NBK7611/ Pinzone, M. R., Celesia, B. M., Di Rosa, M., Cacopardo, B., \& Nunnari, G. (2012). Microbial translocation in chronic liver diseases. International journal of microbiology, 2012, 694629. https://doi.org/10.1155/2012/694629

Prindiville, T. P., Sheikh, R. A., Cohen, S. H., Tang, Y. J., Cantrell, M. C., \& Silva, J., Jr (2000). Bacteroides fragilis enterotoxin gene sequences in patients with inflammatory bowel disease. Emerging infectious diseases, 6(2), 171-174. https://doi.org/10.3201/eid0602.000210

Qin, J., Li, R., Raes, J., Arumugam, M., Burgdorf, K. S., Manichanh, C., Nielsen, T., Pons, N., Levenez, F., Yamada, T., Mende, D. R., Li, J., Xu, J., Li, S., Li, D., Cao, J., Wang, B., Liang, H., Zheng, H., Xie, Y., ... Wang, J. (2010). A human gut microbial gene catalogue established by metagenomic sequencing. Nature, 464(7285), 59-65. https://doi.org/10.1038/nature08821

Qin, J., Li, Y., Cai, Z., Li, S., Zhu, J., Zhang, F., Liang, S., Zhang, W., Guan, Y., Shen, D., Peng, Y., Zhang, D., Jie, Z., Wu, W., Qin, Y., Xue, W., Li, J., Han, L., Lu, D., Wu, P., ... Wang, J. (2012). A metagenome-wide association study of gut microbiota in type 2 diabetes. Nature, 490(7418), 55-60. https://doi.org/10.1038/nature11450

Raisch, J., Dalmasso, G., Bonnet, R., Barnich, N., Bonnet, M., \& Bringer, M. A. (2016). How some commensal bacteria would exacerbate colorectal carcinogenesis?. Medecine sciences : M/S, 32(2), 175-182. https://doi.org/10.1051/medsci/20163202011

Rallabhandi, P., Awomoyi, A., Thomas, K. E., Phalipon, A., Fujimoto, Y., Fukase, K., Kusumoto, S., Qureshi, N., Sztein, M. B., \& Vogel, S. N. (2008). Differential activation of human TLR4 by Escherichia coli and Shigella flexneri 2a lipopolysaccharide: combined effects of lipid A acylation state and TLR4 polymorphisms on signaling. Journal of immunology (Baltimore, Md.: 1950), 180(2), 1139-1147. https://doi.org/10.4049/jimmunol.180.2.1139

Salazar, N., Dewulf, E. M., Neyrinck, A. M., Bindels, L. B., Cani, P. D., Mahillon, J., de Vos, W. M., Thissen, J. P., Gueimonde, M., de Los ReyesGavilán, C. G., \& Delzenne, N. M. (2015). Inulin-type fructans modulate intestinal Bifidobacterium species populations and decrease fecal short-chain fatty acids in obese women. Clinical nutrition (Edinburgh, Scotland), 34(3), 501507. https://doi.org/10.1016/j.clnu.2014.06.001

Salonen, A., Lahti, L., Salojärvi, J., Holtrop, G., Korpela, K., Duncan, S. H., Date, P., Farquharson, F., Johnstone, A. M., Lobley, G. E., Louis, P., Flint, H. J., \& de Vos, W. M. (2014). Impact of diet and individual variation on intestinal microbiota composition and fermentation products in obese men. The ISME journal, 8(11), 2218-2230. https://doi.org/10.1038/ismej.2014.63

Schneider, H., Simmering, R., Hartmann, L., Pforte, H., \& Blaut, M. (2000). Degradation of quercetin-3-glucoside in gnotobiotic rats associated with human intestinal bacteria. Journal of applied microbiology, 89(6), 1027-1037. https://doi.org/10.1046/j.1365-2672.2000.01209.X

Schwiertz, A., Taras, D., Schäfer, K., Beijer, S., Bos, N. A., Donus, C., \& Hardt, P. D. (2010). Microbiota and SCFA in lean and overweight healthy subjects. Obesity (Silver Spring, Md.), 18(1), 190-195. https://doi.org/10.1038/oby.2009.167

Shepherd, E. S., DeLoache, W. C., Pruss, K. M., Whitaker, W. R., \& Sonnenburg, J. L. (2018). An exclusive metabolic niche enables strain engraftment in the gut microbiota. Nature, 557(7705), 434-438. https://doi.org/10.1038/s41586-018-0092-4

Singh, R. K., Chang, H. W., Yan, D., Lee, K. M., Ucmak, D., Wong, K., Abrouk, M., Farahnik, B., Nakamura, M., Zhu, T. H., Bhutani, T., \& Liao, W. (2017) Influence of diet on the gut microbiome and implications for human health. Journal of translational medicine, 15(1), 73. https://doi.org/10.1186/s12967-017$1175-\mathrm{y}$

So, D., Whelan, K., Rossi, M., Morrison, M., Holtmann, G., Kelly, J. T., Shanahan, E. R., Staudacher, H. M., \& Campbell, K. L. (2018). Dietary fiber intervention on gut microbiota composition in healthy adults: a systematic review and meta-analysis. The American journal of clinical nutrition, 107(6), 965-983. https://doi.org/10.1093/ajen/nqy041

Sommer, F., Ståhlman, M., Ilkayeva, O., Arnemo, J. M., Kindberg, J., Josefsson, J., Newgard, C. B., Fröbert, O., \& Bäckhed, F. (2016). The Gut Microbiota 
Modulates Energy Metabolism in the Hibernating Brown Bear Ursus arctos. Cell reports, 14(7), 1655-1661. https://doi.org/10.1016/j.celrep.2016.01.026

Sonnenburg, J. L., Xu, J., Leip, D. D., Chen, C. H., Westover, B. P., Weatherford, J., Buhler, J. D., \& Gordon, J. I. (2005). Glycan foraging in vivo by an intestine-adapted bacterial symbiont. Science (New York, N.Y.), 307(5717), 1955-1959. https://doi.org/10.1126/science.1109051

Springer, A., Fichtel, C., Al-Ghalith, G. A., Koch, F., Amato, K. R., Clayton, J. B., Knights, D., \& Kappeler, P. M. (2017). Patterns of seasonality and group membership characterize the gut microbiota in a longitudinal study of wild Verreaux's sifakas (Propithecus verreauxi). Ecology and evolution, 7(15), 57325745. https://doi.org/10.1002/ece3.3148

Thomas, L. V., Suzuki, K., \& Zhao, J. (2015). Probiotics: a proactive approach to health. A symposium report. The British journal of nutrition, 114 Suppl 1, S1S15. https://doi.org/10.1017/S0007114515004043

Todar K. Pathogenic E coli. Online textbook of bacteriology. Wisconsin: University of Wisconsin-Madison Deparment of Bacteriology; 2007. p. 11-30.

Turnbaugh, P. J., Bäckhed, F., Fulton, L., \& Gordon, J. I. (2008). Diet-induced obesity is linked to marked but reversible alterations in the mouse distal gut microbiome. Cell host \& microbe, 3(4), 213-223. https://doi.org/10.1016/j.chom.2008.02.015

Turnbaugh, P. J., Ley, R. E., Mahowald, M. A., Magrini, V., Mardis, E. R., \& Gordon, J. I. (2006). An obesity-associated gut microbiome with increased capacity for energy harvest. Nature, 444(7122), 1027-1031. https://doi.org/10.1038/nature05414

Valdes, A. M., Walter, J., Segal, E., \& Spector, T. D. (2018). Role of the gut microbiota in nutrition and health. BMJ (Clinical research ed.), 361, k2179. https://doi.org/10.1136/bmj.k2179

van Vliet, M. J., Tissing, W. J., Dun, C. A., Meessen, N. E., Kamps, W. A., de Bont, E. S., \& Harmsen, H. J. (2009). Chemotherapy treatment in pediatric patients with acute myeloid leukemia receiving antimicrobial prophylaxis leads to a relative increase of colonization with potentially pathogenic bacteria in the gut. Clinical infectious diseases : an official publication of the Infectious Diseases Society of America, 49(2), 262-270. https://doi.org/10.1086/599346

Venturi, A., Gionchetti, P., Rizzello, F., Johansson, R., Zucconi, E., Brigidi, P., Matteuzzi, D., \& Campieri, M. (1999). Impact on the composition of the faecal flora by a new probiotic preparation: preliminary data on maintenance treatment of patients with ulcerative colitis. Alimentary pharmacology \& therapeutics, 13(8), 1103-1108. https://doi.org/10.1046/j.1365-2036.1999.00560.x

Vulevic, J., Juric, A., Walton, G. E., Claus, S. P., Tzortzis, G., Toward, R. E., \& Gibson, G. R. (2015). Influence of galacto-oligosaccharide mixture (B-GOS) on gut microbiota, immune parameters and metabonomics in elderly persons. The British journal of nutrition, 114(4), 586-595. https://doi.org/10.1017/S0007114515001889

Walker, A. W., Ince, J., Duncan, S. H., Webster, L. M., Holtrop, G., Ze, X., Brown, D., Stares, M. D., Scott, P., Bergerat, A., Louis, P., McIntosh, F., Johnstone, A. M., Lobley, G. E., Parkhill, J., \& Flint, H. J. (2011). Dominant and diet-responsive groups of bacteria within the human colonic microbiota. The ISME journal, 5(2), 220-230. https://doi.org/10.1038/ismej.2010.118

Walton, G. E., van den Heuvel, E. G., Kosters, M. H., Rastall, R. A., Tuohy, K. M., \& Gibson, G. R. (2012). A randomised crossover study investigating the effects of galacto-oligosaccharides on the faecal microbiota in men and women over 50 years of age. The British journal of nutrition, 107(10), 1466-1475. https://doi.org/10.1017/S0007114511004697

Wexler H. M. (2007). Bacteroides: the good, the bad, and the nitty-gritty. Clinical microbiology reviews, 20(4), 593-621. https://doi.org/10.1128/CMR.00008-07

Whitman, W. B., Coleman, D. C., \& Wiebe, W. J. (1998). Prokaryotes: the unseen majority. Proceedings of the National Academy of Sciences of the United States of America, 95(12), 6578-6583. https://doi.org/10.1073/pnas.95.12.6578

Wu, G. D., Chen, J., Hoffmann, C., Bittinger, K., Chen, Y. Y., Keilbaugh, S. A., Bewtra, M., Knights, D., Walters, W. A., Knight, R., Sinha, R., Gilroy, E., Gupta, K., Baldassano, R., Nessel, L., Li, H., Bushman, F. D., \& Lewis, J. D. (2011). Linking long-term dietary patterns with gut microbial enterotypes. Science (New York, N.Y.), 334(6052), 105-108. https://doi.org/10.1126/science.1208344

Xu, Z., \& Knight, R. (2015). Dietary effects on human gut microbiome diversity. The British journal of nutrition, 113 Suppl(Suppl 0 ), S1-S5. https://doi.org/10.1017/S0007114514004127

Lordan, C., Thapa, D., Ross, R. P., \& Cotter, P. D. (2020). Potential for enriching next-generation health-promoting gut bacteria through prebiotics and other

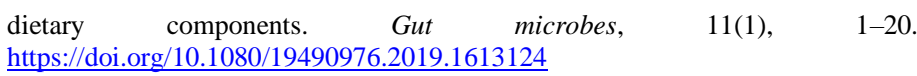

